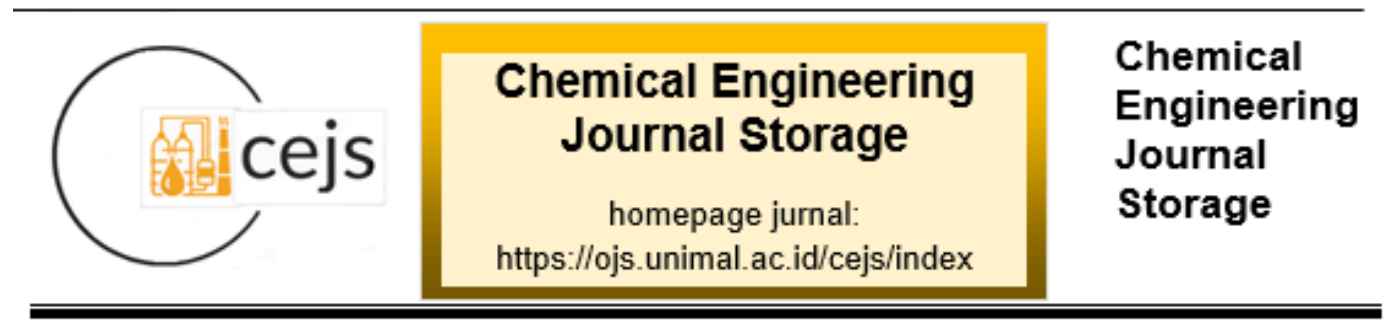

\title{
STUDI AKURASI MODEL PEMBAKARAN TERHADAP PREDIKSI TEMPERATUR PADA NYALA METANA TAK PRACAMPUR MENGGUNAKAN COMPUTATIONAL FLUID DYNAMICS (CFD)
}

\author{
Rido Lumban Tobing, Wusnah, Novi Sylvia, Azhari, Nasrul ZA \\ Jurusan Teknik Kimia Universitas Malikussaleh, wusnah@unimal.ac.id
}

\begin{abstract}
It cannot be denied that the combustion system has driven the advancement of the world economy and society since humans used fire. Apart from providing benefits to humans, the combustion system also provides losses in gas emissions that can damage the environment. Various efforts have been made to improve the combustion system. Computational fluid dynamics (CFD) plays an important role and is used as a standart tool in most firms and the consulting industry. This study aims to show the performance of the combustion system model to predict the temperature of methane flames using the computational fluid dynamics (CFD) method with several combustion models available on anysys fluent $2020 \mathrm{R} 1$, namely the eddy dissipation concept and non premixed combustion. The result of this study prove that the eddy dissipation concept is the best model compared to the non premixed combustion model. Qualitatively the temperature model eddy dissipation concept adds experimental data values, where the temperature achieved by eddy dissipation concept model reaches $1840 \mathrm{~K}$ at position of about $700 \mathrm{~mm}$ or $0.7 \mathrm{M}$. by default the combustion non premixed model graphs trend following experimental data, but the highest peak only reaches $1452 \mathrm{~K}$ at a position of about 540 or $0.54 \mathrm{M}$ above the nozzle, while the experimental data reaches $1816 \mathrm{~K}$ at a position around $560 \mathrm{~mm}$ or $0.56 \mathrm{M}$. Researchers hope that the result of this research can be an input the future in the premixed flame combustion system in the Computational Fluid Dynamics (CFD) method.
\end{abstract}

Keywords: CFD, Methane, Combustion Model, and Non-premixed Combustion

\begin{abstract}
Abstrak
Tidak dapat dipungkiri bahwa pembakaran telah mendorong kamajuan dunia ekonomi dan masyarakat sejak manusia menggunakan api. Selain memberikan manfaat bagi manusia, pembakaran juga menghasilkan kerugian dalam hal emisi gas yang dapat merusak lingkungan.Berbagai upaya telah dilakukan untuk meningkatkan efisiensi pembakaran. Computational Fluid Dynamics( CFD) memainkan peranan penting dan digunakan sebagai alat standar di sebagian besar perusahaan dan industri konsultan. Penelitian ini bertujuan untuk menyelidiki kinerja model pembakaran untuk memprediksi temperatur pada nyala metana menggunakan metode Computational Fluid Dynamics (CFD) dengan beberapa model pembakaran yang tersedia pada Ansys Fluent 2020 R1 yaitu Eddy Dissipation Concept dan Non Premixed Combustion. Hasil dari penelitian ini membuktikan bahwa model pembakaran Eddy Dissipation Concept merupakan model yang terbaik dibandingkan dengan model Non Premixed Combustion.secara kualitatif temperatur model Eddy dissipation Concept yang mendekati nilai data eksperimen, dimana suhu yang dicapai model Eddy dissipation Concept mencapai $1840 \mathrm{~K}$ pada posisi sekitar $700 \mathrm{~mm}$ atau $0.7 \mathrm{~m}$. Secara kuantitatif model Non premixed Combustion tren grafiknya mengikuti data eksperimen namun puncak tertingginya hanya mencapai $1452 \mathrm{~K}$ pada posisi sekitar 540 atau $0.54 \mathrm{~m}$ di atas nozzle, sedangkan data eksperimen suhunya mencapai $1816 \mathrm{~K}$ pada posisi sekitar $560 \mathrm{~mm}$ atau $0.56 \mathrm{~m}$.peneliti berharap hasil dari penelitian ini dapat menjadi masukan kedepannya dalam mensimulasikan pembakaran nyala tak pracampur pada metode Computational Fluid Dynamics (CFD).
\end{abstract}

Kata Kunci: $C F D$, Metana, Model Pembakaran dan pembakaran nyala tak pracampur 


\section{PENDAHULUAN}

Pembakaran adalah proses yang sangat kompleks berkaitan dengan interaksi fenomena fisik dan kimia termasuk aliran, turbulensi, termodinamika, reaksi kimia, radiasi, kepunahan, dan pengapian. Hampir semua sistem pembakaran dalam berbagai peralatan seperti mesin roket, mesin pesawat, kiln dan cerobong asap di industri diimplementasikan dalam lingkungan yang bergejolak, dengan tujuan meningkatkan laju pembakaran. Panas dilepaskan dari reaksi kimia, tetapi proses ini melibatkan penyebaran perpindahan panas dan dinamika fluida sehingga interpretasi teoritis dapat diturunkan menggunakan pemahaman tentang kimia, fisika, mekanika fluida dan matematika terapan (Wusnah, 2018).

Dalam proses pembakaran fenomena-fenomena yang terjadi antara lain interaksi proses-proses kimia dan fisika, pelepasan panas yang berasal dari energi ikatan-ikatan kimia, proses perpindahan panas, proses perpindahan massa, dan gerakan fluida (Firmansyah, 2008). Pada proses pembakaran, bahan bakar dan oksidizer (biasanya udara) dikontakkan (mix) dan dibakar. Jika ditinjau dari mekanisme kontak antara fuel dan oksidizer maka proses pembakaran dapat dibagi menjadi 2 yaitu premix dan non-premix. Premix adalah bahan bakar dan oksidizer dicampur terlebih dahulu kemudian dibakar (dengan ignition phenomena) sedangkan non-premix adalah proses pencampuran dan pembakaran bahan bakar dengan oksidizer terjadi secara simultan. Masing-masing metode ini juga dapat memiliki rezim aliran yang berbeda. (Warnatz.et.al, 2006).

Temperatur nyala (Flame Temperatures) adalah suhu maksimum nyala bahan bakar yang terjadi apabila tidak ada kebocoran panas ke sekelilingnya. Suhu nyala adibatik diperlukan untuk mngetahui berapa besar panas yang yang terjadi ketika bahan bakar tersebut dibakar. Flame temperatur juga bervariasi sesuai dengan rasiomasingmasing komponen dalam campuran yang mudah terbakar. jika campuran tidak masuk pembakar dalam komposisi optimal, bahan bakar kelebihan atau oksidan tidak berpartisipasi dalam reaksi dan gas inert seperti komponen berlebih menurunkan suhu nyala api.Turbulensi merupakan suatu fenomena yang tidak linier, tiga dimensi, dan berubah terhadap waktu. Pada aliran turbulen, secara kontinu terbentuk pusaran pusaran besar yang kemudian terpecah menjadi pusaran-pusaran yang lebih kecil dan akhirnya menghilang (dissipasi).

Pemodelan pembakaran turbulen bertujuan mencari klosur untuk suku sumber kimia pada persamaan perpindahan spesies (species transport equations). Pelaksanaan klosur ini menghadapi kesulitan karena laju reaksi kimia biasanya merupakan fungsi non-linear dari komposisi dan temperatur. Akibatnya, laju reaksi rata-rata tidak dapat dinyatakan secara sederhana sebagai fungsi temperatur ratarata dan konsentrasi rata-rata. Pendekatan langsung untuk mengevaluasi suku sumber kimia adalah mengembangkan deret Taylor terhadap laju reaksi kimia, sehingga memuat momen lebih tinggi dari fluktuasi temperatur, varian dan co-varian. Karena adanya interaksi antara turbulen dan reaksi kimia inilah yang menjadi penentu dalam stabilitas nyala dan pembentukan jelaga dalam sistem pembakaran.

Beberapa model telah dikembangkan untuk memodelkan interaksi tersebut. Eddy Dissipation Model (EDM) dikembangkan oleh Magnussen dan Hjertager (1977), untuk memprediksi reaksi pembakaran aliran turbulen. Model EDM mengasumsikan bahwa reaksi berlangsung sangat cepat. Ketika reaktan bercampur pada level molekular, secara seketika langsung membentuk produk, sehingga laju reaksi keseluruhan dikendalikan oleh pencampuran turbulen. Konsep flamelet seperti yang diajukan oleh Peters (1984) didasarkan pada pemikiran adanya struktur nyala laminar lokal, yang disebut flamelet, terjadi pada nyala difusi aliran laminar lawan-arah. Karena itu, nyala turbulen diperlakukan sebagai sekumpulan flamelet tipis yang terkungkung di dalam medan alir turbulen. Metode transported Probability Density Function (PDF) yang dikembangkan oleh Pope (1985) yang telah diterapkan pada simulasi aliran turbulen selama hampir 30 tahun. Metode ini, bersama dengan model RKT, merupakan salah satu model yang cukup menjanjikan untuk pengembangan di masa yang akan datang. Ketika ditinjau persamaan perpindahan PDF gabungan kecepatan, frekuensi turbulen dengan komposisi, maka persamaan tersebut telah lengkap (tertutup) sehingga tidak lagi memerlukan pemodelan baik untuk turbulensi maupun suku sumber kimianya. Model Eddy Dissipation Concept (EDC) adalah merupakan model pembakaran tingkat lanjut yang secara teoritis dapat diaplikasikan untuk laju terbatas (finite rate). Model EDC adalah variasi dari model Eddy Dissipasi klasik yang berdasarkan pada konsep yang dilakukan oleh Magnussen dan Hjertager (1976). Pada pendekatan klasik, laju reaksi diasumsikan dikontrol oleh turbulensi, maka perhitungan dari kinetika kimia Arrhenius dapat dihindari.

Bunsen burner merupakan alat pembakar (burner) pertama yang dapat menghasilkan nyala api premix (premix flame). Alat ini ditemukan oleh Robert William Bunsen (1811-1899) pada 
tahun 1855. Bunsen burner ini menggunakan prinsip pengaturan aliran campuran udara-bahan bakar gas secara kontinyu

Metana adalah hidrokarbon yang sederhana yang berbentuk gas dengan rumus $\mathrm{CH}_{4}$. Sebagai komponen gas utama, metana merupakan sumber bahan bakar utama. Metana merupakan gas alam yang sangat melimpah di atmosfer pada saat ini, serta merupakan salah satu penyebab penipisan lapisan ozon dan berdampak pada terjadinya pemanasan global (Yi lu etal.,1999)

Udara merujuk pada campuran gas yang terdapat di permukaan bumi. Udara tidak tampak mata, tidak berbau dan tidak berasa. Udara adalah atmosfer yang ada disekeliling bumi ini, dalam udara terdapat oksigen $\mathrm{O}_{2}$ untuk bernafas, $\mathrm{CO}_{2}$ untuk proses fotosintesis oleh khlorofil daun dan ozon $\mathrm{O}_{3}$ untuk menahan sinar ultraviolet dari matahari (Sunu, 2001)

Polusi udara oleh gas buang merupakan gangguan terhadap lingkungan. Komponen-komponen gas buang yang membahayakan itu diantara lain adalah asap hitam, hidrokarbon tidak terbakar, karbon monoksida (CO), oksida nitrogen (NO) dan $\mathrm{NO}_{2}$. $\mathrm{NO}$ dan $\mathrm{NO}_{2}$ biasanya di nyatakan dengan $\mathrm{NO}_{x}$ (Arismunandar, $2002: 51$ )

Karbon monoksida (CO) adalah suatu gas yang tidak bewarna, tidak berbau dan tidak berasa dengan jumlah sedikit di udara sekitar 0,1 ppm yang berada di lapisan atmosfer, oleh karena itu lingkungan yang tercemar oleh gas karbon monoksida (CO) tidak dapat dilihat oleh mata. Gas karbon monoksida (CO) diproduksi oleh proses pembakaran yang tidak sempurna dari bahan - bahan yang mengandung karbon. Gas karbon monoksida (CO) dapat berbentuk cairan pada suhu dibawah $-192{ }^{\circ} \mathrm{C}$, gas karbon monoksida (CO) sebagian besar berasal dari pembakaran bahan bakar fosil dengan udara, berupa gas buangan (Wardhana, 2001).

Didukung dengan cepatnya perkembangan sumber daya computer yang kuat dan pengembangan paket perangkat lunak CFD tujuan umum, dalam beberapa dekade terakir pertumbuhan aplikasi CFD yang berkembang dalam desain teknik, analisis, penelitian, dan aplikasi telah banyak memberi banyak manfaat yang besar. CFD telah terbukti menjadi alat yang berharga untuk melengkapi temuan eksperimental dalam studi aliran fluida, termaksud aliran reaksi kimia dan pembakaran.

Ansys fluent merupakan perangkat lunak dalam computer yang digunakan untuk mensimulasikan aliran fluida dan perpindahan panas. Aliran dan perpindahan panas dari berbagai fluida dapat disimulasikan pada bentuk/geometri yang rumit. Dengan menggunakan program Fluent, dapat diketahui parameterparameter aliran dan perpindahan panas yang diinginkan, distribusi temperatur, dan pola aliran fluida yang terjadi dapat diketahui pada tiap titik yang terdapat dalam sistem yang dianalisa. Model mesh dinamis dalam Ansys Fluent 2020 R1 dapat digunakan untuk memodelkan aliran di mana bentuk domain berubah seiring waktu karena gerakan pada batas domain. Model mesh dinamis dapat diterapkan untuk aliran tunggal atau multifasa. Persamaan transport generik berlaku untuk semua persamaan model, seperti turbulensi, energi, spesies, fase, dan lainnya. Model mesh dinamis juga dapat digunakan untuk aplikasi kondisi mantap (steady state)

\section{METODOLOGI PENELITIAN}

Penelitian dilakukan di Laboratorium Modeling Jurusan Teknik Kimia Universitas Malikussaleh dan ruang belajar Mahasiswa sendiri. Penelitian disimulasikan menggunakan software, untuk mengkaji prediksi temperatur pada nyala metana tak pracampur. Software yang digunakan adalah perangkat lunak komersil ANSYS FLUENT 2020 R1, Origin pro 8, Get Data Graph.

Bahan bakar yang digunakan adalah gas metana dengan suhu $300 \mathrm{~K}$ dan komposisi dalam persen volume diantaranya metana $\left(\mathrm{CH}_{4}\right)$ 22,1\%, hidrogen $\left(\mathrm{H}_{2}\right)$ 33,2 \% dan nitrogen $\left(\mathrm{N}_{2}\right)$ 44,7 \% dengan kecepatan aliran $42,15 \mathrm{~m} / \mathrm{s}$. Oksidator yang digunakan adalah udara dengan suhu $300 \mathrm{~K}$ dan komposisi dalam persen volume dianmtaranya oksigen $\left(\mathrm{O}_{2}\right) 23,3$

$\%$ dan nitrogen $\left(\mathrm{N}_{2}\right) 76,7 \%$ dengankecepatan aliran $0,3 \mathrm{~m} / \mathrm{s}$. Geometri terdiri dari nosel bahan bakar, nosel oksidizer dan domain dengan ukuran berturut-turut $8 \mathrm{~mm}, 140 \mathrm{~mm}$ dan 1000 x 2000 $\mathrm{mm}^{2}$. Skema represitasi api dan domain ditunjukkan pada gambar 1 . 

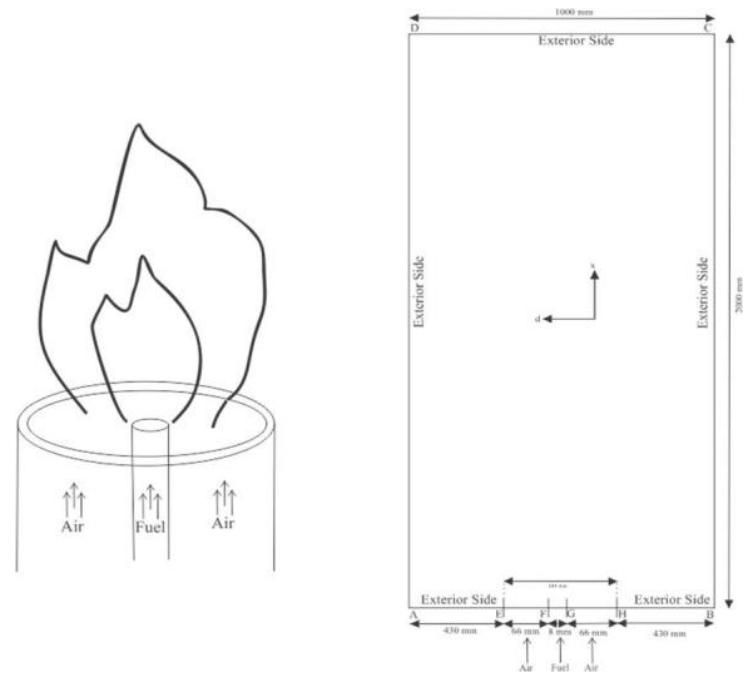

Gambar 1. Skema represitasi api dan domain

Langkah-langkah yang dilaksanakan pada penelitian ini secara umum dimulai dari pembuatan geometri selanjutnya mengatur mesh, pemilihan model laju alir turbulen, pemilihan model pembakaran, dan mengatur boundary condition. Metode simulasi digunakan couple dan dihitung sebanyak $1000-2000$ kali iterasi. Hasil perhitungan akan digambarkan dalam bentuk grafik dan gambar, selanjutnya semua hasil prediksi yang didapat akan divalidasi dengan data eksperimen nyala metana (Wusnah; Brookes dan Moss) yang diperoleh dari literatur.

\section{HASIL DAN PEMBAHASAN}

Penelitian ini mensimulasikan pengaruh model pembakaran terhadap prediksi temperatur pada nyala tak pracampur. Pemodelan nantinya akan menganalisa pengaruh model pembakaran yang ada pada Ansys Fluent 2020 R1 komersial terhadap prediksi temperatur dari proses pembakaran nyala tak pracampur dengan bahan bakar metana. Prediksi dilakukan dengan mensimulasikan proses pembakaran gas metana nyala tak pracampur dengan model Eddy Dissipation Concept (EDC) dan model Non Premixed Combustion yang tersedia dalam Ansys Fluent 2020 R1 yang bertujuan untuk membandingkan kedua model pembakaran tersebut.

Gambar 2 menunjukkan data grafik prediksi medan alir yang dihasilkan dari simulasi nyala api metana yang dihitung menggunakan model Transition SST. Gambar (a) Eddy dissipation Concept, Gambar (b) Non Premixed Combustion.

Gambar 3 menunjukkan kontur profil Temperatur yang dihasilkan dari simulasi nyala api metana yang dihitung menggunakan model pembakaran (a) Eddy Dissipation Concept, (b) Non Premixed Combustion.

Data prediksi Temperatur pada $\mathrm{x}=0,5 \mathrm{~m}$ ditunjukkan pada gambar 4. Profil temperatur dari kedua model tersebut disajikan kedalam bentuk grafik untuk memvalidasi model yang paling mendekati data eksperimen ditunjukkan pada gambar 5 yang menunjukkan hasil prediksi temperatur kedua model pembakaran. 


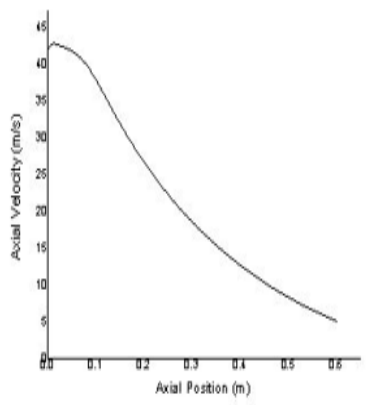

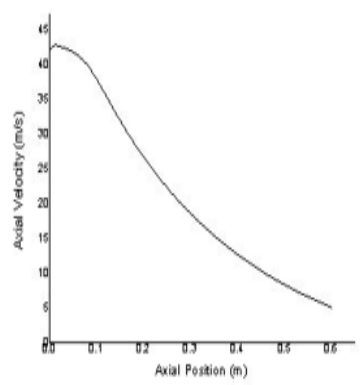

b

Gambar 2. Grafik Prediksi Medan Alir Aksial Nyala Metana Tak Pracampur Model Transition SST. Gambar (a) Eddy dissipation Concept, Gambar (b) Non Premixed Combustion.

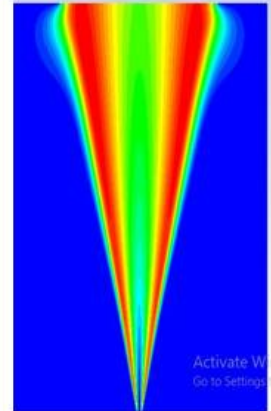

a

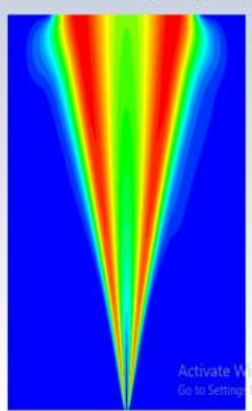

b

Gambar 3. Prediksi Profil Temperatur Nyala Metana Tak Pracampur Model pembakaran. Gambar (a) Eddy Dissipation Concept, (b) Non Premixed Combustion.

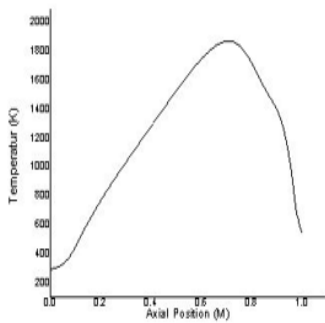

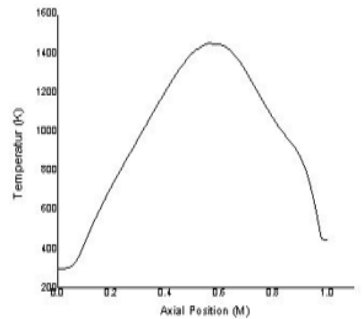

b

Gambar 3. Grafik Prediksi Temperatur Nyala Metana Tak Pracampur Model pembakaran (a) Eddy Dissipation Concept (b) Non Premixed Combustion.

\section{PREDIKSI TEMPERATUR}

Berdasarkan hasil simulasi prediksi Temperatur, model yang digunakan adalah Eddy Dissipation Concept dan Non Premixed Combustion. Profil Model Pembakaran dari kedua model tersebut disajikan kedalam bentuk grafik untuk memvalidasi model yang paling mendekati data eksperimen ditunjukkan pada Gambar 4 


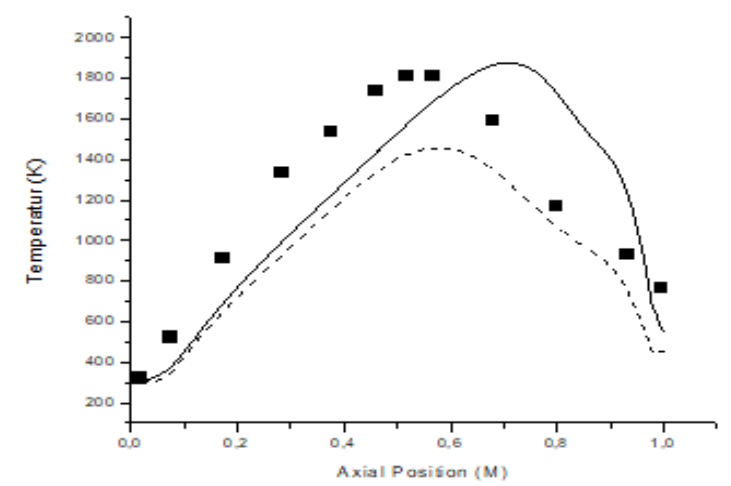

Gambar 4 Grafik Prediksi Temperatur Aksial dan Data Eksperimen (simbol = data eksperimen; garis = data simulasi; garis padat — Eddy Dissipation Concept;

garis putus-putus - - - Non Premixed Combustion.

Gambar 4 menunjukkan hasil prediksi Temperatur aksial beberapa model pembakaran dan dibandingan dengan data ekaperimen. Simbol pada Gambar 4. mewakili data eksperimen sedangkan garis menampilkan hasil prediksi beberapa model pembakaran yang tersedia pada Ansys Fluent 2020 R1. Data diambil pada garis tengah nyala api pada $\mathrm{x}=0,5 \mathrm{~m}$ dan kedua model pembakaran memberikan prediksi yang berbeda

Dilihat dari grafik pada Gambar 4, data eksperimen menunjukan itu merupakan posisi stokiometri dimana nyala suhu tertinggi api terjadi pada posisi sekitar $560 \mathrm{~mm}$ atau $0.56 \mathrm{~m}$ di atas nozzle dengan suhu 1816 K.Sedangkan data simulasi secara kualitatif profil temperatur dari kedua model pembakaran,model Eddy Dissipation Concept yang mendekati nilai data eksperimen dimana nyala suhunya mencapai $1840 \mathrm{~K}$, sedangkan model pembakaran Non premixed Combustion nyala suhunya hanya mencapai $1452 \mathrm{~K}$. Secara kuantitatif hasil dari temperatur aksial di inti nyala api pada model pembakaran Eddy Dissipation Concept yang memiliki nilai yang lebih dekat data eskperimen dibanding dengan model pembakaran Non Premixed Combustion.

Model Pembakaran Eddy Dissipation Concept mampu memprediksi dengan baik.dimana nyala suhu api nya mencapai $1840 \mathrm{~K}$ pada posisi sekitar $700 \mathrm{~mm}$ atau $0.7 \mathrm{~m}$ di atas nozzle, dan nyala suhu apinya tidak berbanding jauh dengan nyala suhu api eksperimen yang suhu nya mencapai $1816 \mathrm{~K}$ pada posisi sekitar $560 \mathrm{~mm}$ atau $0.56 \mathrm{~m}$.

Model Non Premixed Combustion secara kuantitatif grafik prediksi temperaturnya mengikuti laju grafik data eksperimen, namun puncak tertinggi nyala apinya hanya mencapai $1452 \mathrm{~K}$ pada posisi sekitar 540 atau $0.54 \mathrm{~m}$ di atas nozzle. Hal ini disebabkan model Non premixed Combustion tidak mampu mendekati posisi stoikiometri pada data eksperimen.

Perbedaan temperatur yang dihasilkan oleh kedua model pembakaran di karenakan prediksi model Eddy Dissipation concept mampu mendekati posisi stoikiometri pada data eksperimen. Penyebab perbedaan temperatur yang di hasilkan kedua model tersebut dapat juga kita lihat dipenjelasan Gambar 4.7.Validasi dari simulasi kedua model Pembakaran pada Ansys Fluent 2020 R1 tersebut dapat disimpulkan bahwa model pembakaran Eddy Dissipation Concept adalah model yang cukup baik untuk mensimulasikan nyala metana tak pracampur.

\section{PREDIKSI FRAKSI MASSA}

Gambar 5 menunjukan perbandingan fraksi massa $\mathrm{CH}_{4}$ dan $\mathrm{CO}_{2}$ prediksi model Eddy Dissipation Concept dengan model Non premixed Combustion. Data dari kedua model percobaan menunjukan bahwa fraksi massa $\mathrm{CH}_{4}$ terus menurun selama proses pembakaran. Dan pada fraksi massa $\mathrm{O}_{2}$ pada model Non premixed Combustion laju grafiknya sedikit lebih baik dibandingkan dengan model Eddy Dissipation Concept, yang mana pada model Eddy Dissipation Concept grafik nya pada ketinggian $800 \mathrm{~mm}-900 \mathrm{~mm}$ tidak dapat mengikuti data kemiringan tetapi pada saat mencapai ketinggian diatas $900 \mathrm{~mm}$ di atas nosel laju grafik kembali

pulih. 

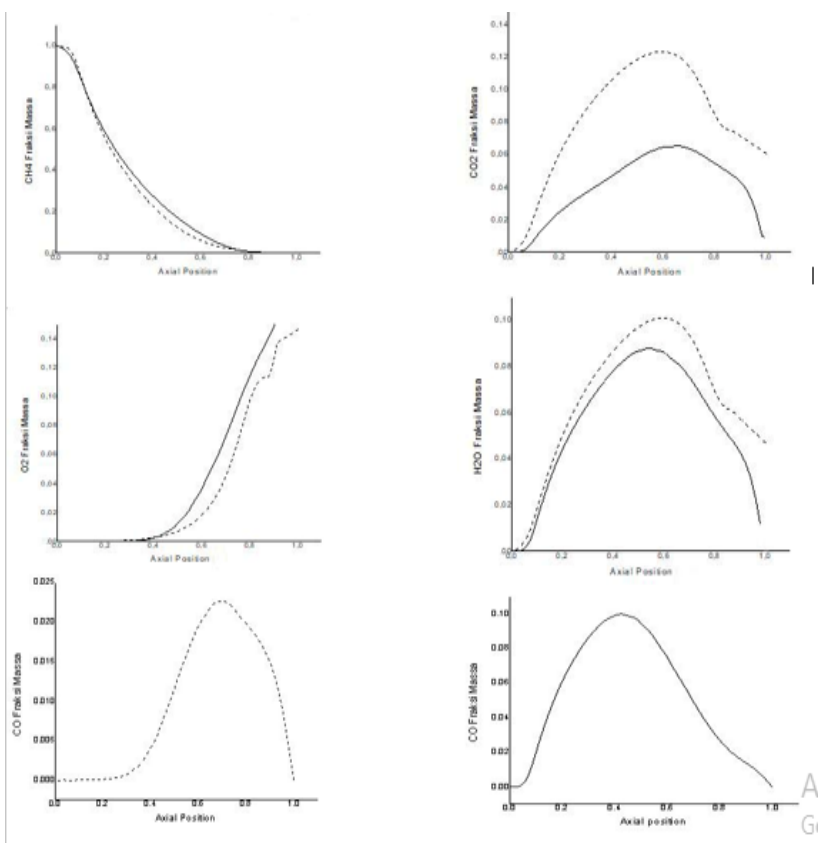

Gambar 5Perbandingan fraksi massa spesies hasil pembakaran model Eddy Dissipation Concept dengan model Non Premixed Combustion $($ Line $=$ Non premixed Combustion, Dot line $=$ Eddy Dissipation Concept)

Dan berkenaan dengan Fraksi massa hasil pembakaran yaitu $\mathrm{CO}_{2}$ dan $\mathrm{H}_{2} \mathrm{O}$ pada kedua model menunjukan bahwa fraksi massa $\mathrm{CO}_{2}$ pada model Non premixed Combustion lebih sedikit yang terbentuk dibandingkan dengan Fraksi massa $\mathrm{H}_{2} \mathrm{O}$ nya, dapat kita perhatikan pada Gambar 5, $\mathrm{H}_{2} \mathrm{O}$ yang terbentuk lebih banyak dibandingan $\mathrm{CO}_{2}$, hal ini berhubungan dengan Gambar 4 yang menjadi salah satu menyebabkan temperatur nyala tertinggi pada model Non Premixed Combustion hanya mencapai $1452 \mathrm{~K}$, tidak mencapai temperatur eksperimen dikarenakan $\mathrm{H}_{2} \mathrm{O}$ yang di hasilkan lebih banyak.

Berbanding terbalik dengan hasil fraksi massa $\mathrm{CO}_{2}$ dan $\mathrm{H}_{2} \mathrm{O}$ yang dihasilkan pada model Eddy Dissipation Concept, pada saat fraksi massa $\mathrm{CH}_{4}$ dan $\mathrm{O}_{2}$ mulai menurun, $\mathrm{CO}_{2}$ dan $\mathrm{H}_{2} \mathrm{O}$ mulai meningkat sampai mencapai posisi stoikiometri dan mulai turun setelahnya. Dan fraksi massa $\mathrm{H}_{2} \mathrm{O}$ yang dihasilkan oleh model ini lebih sedikit yang di hasilkan dibandingkan dengan fraksi massa $\mathrm{H}_{2} \mathrm{O}$ yang dihasilkan pada model Non Premixed Combustion. Dan $\mathrm{CO}_{2}$ yang terbentuk pada Eddy dissipation Concept lebih banyak dibandingkan dengan $\mathrm{H}_{2} \mathrm{O}$ dan $\mathrm{CO}$

Pada grafik Fraksi massa CO model Non Premixed pada Gambar 5 dapat kita lihat fraksi massa CO yang terbentuk lebih banyak dari pada Fraksi Massa CO pada model Eddy Dissipation Concept, pada model Non premixed Combustion, puncak tertinggi fraksi massa $\mathrm{CO}$ yang terbentuk pada ketinggian 0,42 $\mathrm{M}$ dengan nilai 0,099 mol. Sedangkan model Eddy Dissipation Concept puncak tertinggi CO yang terbentuk pada ketinggian $0.67 \mathrm{M}$ dengan nilai $0,023 \mathrm{~mol}$.

Dari Gambar 5 pada grafik $\mathrm{CO}$ dan $\mathrm{CO}_{2}$ dapat kita lihat pada model Non premixed Combustion, fraksi massa $\mathrm{CO}$ yang terbentuk lebih banyak dibandingkan Fraksi massa $\mathrm{CO}_{2}$, hal ini merupakan salah satu penyebab mengapa temperatur pada model ini tidak dapat mendekati temperatur eksperimen. Berbanding terbalik dengan Model Eddy Dissipation Concept, $\mathrm{CO}$ yang terbentuk lebih sedikit dibanding $\mathrm{CO}_{2}$ yang dihasilkan. Dari Gambar 4 dan Gambar 5dapat kita simpulkan bahwa pada model Eddy Dissipation Concept lebih baik dibanding dengan model Non Premixed Combustion baik secara kuantitatif maupun kualitatif.

\section{KESIMPULAN}

Berdasarkan hasil simulasi prediksi temperatur dari nyala metana turbulen tak pracampur dan pengolahan data yang telah dijelaskan di bab sebelumnya, maka dapat diperoleh beberapa kesimpulan dari penelitian ini diantaranya.

1. Prediksi temperatur aksial dari nyala metana disimulasikan dengan dua model yang tersedia dalam Ansys Fluent 2020 R1 diantaranya Eddy Dissipation Concept dan Non Premixed Combustion.

2. Secara kualitatif model Eddy Dissipation Concept memprediksi profil temperatur mendekati profil

3. temperatur eksperimen yang mencapai suhu diatas $1840 \mathrm{~K}$ sedangkan model Non Premixed Combustion hanya mencapai $1452 \mathrm{~K}$. 
4. Secara kuantitatif grafik temperatur model Non Premixed Combustion dengan grafik data eksperimen memiliki laju grafik yang mirip hanya saja suhu tertinggi pada model Non Premixed Combustion hanya mencapai $1452 \mathrm{~K}$, sedangkan eksperimen mencapai $1800 \mathrm{~K}$.

5. Pada hasil Reaksi Pembakaran terhadap kedua Model, model eddy Dissipation Concept lebih baik dari pada model Non Premixed Combustion dengan menghasilkan emisi gas CO lebih rendah.

6. Model Eddy Dissipation Concept menjadi saran sebagai pilihan yang di gunakan dalam model pembakaran nyala tak pracampur pada Ansys Fluent 2020 R1

\section{DAFTAR PUSTAKA}

ANSYS Inc (2016) ANSYS Fluent Theory Guide, Release 15.0

Sawyer, R. F (2009) science based policy for addressing energy and enviromental Problems. Proc. Combust. Inst. , 32:45-56.

Wusnah, (2008) 'Numerical study of influences of crosswind and additional steam on the flow field and temperature of propane non-premixed turbulence flame Numerical study of influences of crosswind and additional steam on the flow field and temperature of propane non- pr'. doi: 10.1088/1757899X/334/1/012023

Versteeg, H. and Malalasekra W. (2009) An introduction to Computational Fluid Dynamics.

Elwina, (2012) 'aspek model pembakaran terhadap prediksi jelaga pada nyala turbulen tak-pracampur'

US Energy Information Administration (2016) International Energy Outlook 2016, Washington'

Castiñeira, D. (2006), A Computational Fluid Dynamics Simulation Model for flare analysis and control.

Sanders J.P.H and A.P.G.G Lamers, "Modeling and Calculation of Turbulent

Lifted Diffusion Flames “, Combust. Flame, vol. 96, pp.22-33, 1994

Frenklach,M (2002). Reaction mechanism of soot Formation in flames. Physical chemical physics, 4:20282037

Mahandri, CP. (2010). Fenomena flame lift-up pada pembakaran premixed gas propana [skripsi]. Jakarta; universitas indonesia.

Julio Rendón; Francisco Cadavid; Andrés Amell. Flame structure simulation in a methane/air co-flow partially premixed burner. Fac. Ing. Univ. Antioquia ,Junio 2008, $N$. $^{\circ} 44$. pp. 61-74.

Cheung, L.K. Sze, C.S. C.W. Leung, Appearance, temperature, and NOx emission of two inverse diffusion flames with different port design, Combust. Flame 144 (2006)

Sunu, P. (2001). Melindungi Lingkungan dengan menerapkan ISO 14001. Penerbit: PT Gramedia Widiasarana Indonesia. Jakarta.

Wardhana, W.A. (2001). Dampak Pencemaran Lingkungan. Penerbit: Andi Offset.Yogyakarta.

US Energy Information Administration (2016) International Energy Outlook 2016, Washington

Frenklach, M. (2002). Reaction mechanism of soot formation in flames. Physical Chemistry Chemical Physics, 4:2028-2037.

Frenklach, M. and Wang, H., (1994), Detailed mechanism and modeling of soot particle formation. In H. Bockhorn (Ed.), Soot formation in combustion (pp.165-190), Springer-Verlag, Berlin

Djojodihardjo, Dr. Ir. Harijono., (1983). Mekanika Fluida. Bandung: Erlangga

Firmahsyah, Rachmat Haris. (2008). Kestabilan dan Panjang Nyala Api Premix Akibat Variasi Diameter Dalam Ding menggunakan Gas Propana pada Bunsen Burner [skripsi]. Kedah: Universitas Utara Malaysia

Sihana. (2010). Analysis of thermal system. Jogjakarta: Universitas Gajah Mada Tersedia dari: 
Rido Lumban Tobing / Chemical Engineering Journal Storage $1: 1$ (Agustus 2021) 42-50

http://sihana.staff.ugm.ac.id/. [Diakses tanggal 2 Desember 2018].

Wong; Yi Lu C.; Y. S. N.F.Y. Tam; Y. Ye and P. Lin. (1999). Methane Flux and Production from Sediments of $a$ 